\title{
The Supreme Court and the Constitutional Right to Privacy
}

Neil Snortland, University of Arkansas at Little Rock

Since its creation in 1965 , the constitutional right of privacy has been difficult to understand, even contradictory. This may be explained as the result of the incremental implementation of the sweeping language of Griswold v. Connecticut, with privacy coming into conflict with other rights such as the freedom of the press. In addition, the initial criticisms of Griswold's synoptic privacy reasoning intensified when Roe $v$. Wade provoked potent political opposition. These influences combined with the changing membership on the Supreme Court to produce an evaporation of privacy language from recent decisions, most notably Webster v. Reproductive Health Services and Cruzan $v$. Director, Missouri Department of Health. Furthermore, the Court is transforming Roe's declaration of privacy as a "fundamental right" protected by "strict scrutiny" into a "liberty interest" protected by the relaxed standard of "rational-basis scrutiny." Finally, Rehnquist and Scalia want to give a narrow historical interpretation to any "liberty interest," thus limiting the application of privacy to other areas of constitutional law.

\section{Introduction}

The Constitution protects privacy. This simple proposition is explicit or implicit in numerous Supreme Court decisions. Even Robert Bork, that most assiduous critic of a general constitutional right of privacy, admitted "[t]here is a lot of privacy in the Constitution" (Fisher 1990, 1232). However, attempts to understand the scope of a constitutional right to privacy generally conclude in puzzlement or ambiguity. For example, privacy protects people who, in their homes, view obscene materials showing homosexual acts; it does not protect people who, in their homes, perform homosexual acts or possess child pornography. Nor does it protect those who wish to view obscene films in a theater only with other consenting adults. An expectation of privacy protects telephone conversations at public booths; it does not protect trash bags left on the curb. Privacy, as a fundamental right, protects women who decide to have an abortion but, for example, unlike the fundamental right to a lawyer, carries no corresponding state obligation to fund such choices by poor women even when medically necessary. Privacy, then, remains "the newest and still broadly undefined realm of constitutional law" which is "extremely difficult" to explain satisfactorily (Abraham 1987, 125-126). To some the Court's privacy decisions are "confusing and contradictory" (Curry 1989, 419), and even among state supreme courts the "right to privacy has developed and grown in a haphazard manner..., [making] it very difficult to find common theories and principles which constitute a right to privacy" (Domino 1990, 13). 


\section{The Supreme Court and the Constitutional Right to Privacy}

Neil Snortland, University of Arkansas at Little Rock

Since its creation in 1965 , the constitutional right of privacy has been difficult to understand, even contradictory. This may be explained as the result of the incremental implementation of the sweeping language of Griswold v. Connecticut, with privacy coming into conflict with other rights such as the freedom of the press. In addition, the initial criticisms of Griswold's synoptic privacy reasoning intensified when Roe $v$. Wade provoked potent political opposition. These influences combined with the changing membership on the Supreme Court to produce an evaporation of privacy language from recent decisions, most notably Webster v. Reproductive Health Services and Cruzan $v$. Director, Missouri Department of Health. Furthermore, the Court is transforming Roe's declaration of privacy as a "fundamental right" protected by "strict scrutiny" into a "liberty interest" protected by the relaxed standard of "rational-basis scrutiny." Finally, Rehnquist and Scalia want to give a narrow historical interpretation to any "liberty interest," thus limiting the application of privacy to other areas of constitutional law.

\section{Introduction}

The Constitution protects privacy. This simple proposition is explicit or implicit in numerous Supreme Court decisions. Even Robert Bork, that most assiduous critic of a general constitutional right of privacy, admitted "[t]here is a lot of privacy in the Constitution" (Fisher 1990, 1232). However, attempts to understand the scope of a constitutional right to privacy generally conclude in puzzlement or ambiguity. For example, privacy protects people who, in their homes, view obscene materials showing homosexual acts; it does not protect people who, in their homes, perform homosexual acts or possess child pornography. Nor does it protect those who wish to view obscene films in a theater only with other consenting adults. An expectation of privacy protects telephone conversations at public booths; it does not protect trash bags left on the curb. Privacy, as a fundamental right, protects women who decide to have an abortion but, for example, unlike the fundamental right to a lawyer, carries no corresponding state obligation to fund such choices by poor women even when medically necessary. Privacy, then, remains "the newest and still broadly undefined realm of constitutional law" which is "extremely difficult" to explain satisfactorily (Abraham 1987, 125-126). To some the Court's privacy decisions are "confusing and contradictory" (Curry 1989, 419), and even among state supreme courts the "right to privacy has developed and grown in a haphazard manner..., [making] it very difficult to find common theories and principles which constitute a right to privacy" (Domino 1990, 13). 
This paper argues that the current state of the constitutional right to privacy is understandable in light of several factors. First, the Court used an extremely broad, synoptic approach in Griswold v. Connecticut (1965) to establish a fundamental, general right to privacy. However, the privacy of Griswold was synonymous with freedom from outside control or monitoring, and thus inevitably collided with the demands of organized society, specific provisions of the constitution, and other lines of constitutional law, disappointing the libertarian impulse to have government stay out of the lives of citizens. Even John Stuart Mill, who so thoroughly favored liberty in the "struggle between Liberty and Authority," admitted that liberty was not absolute, but could be restricted "to prevent harm to others" (Mill 1951, 85, 96). As Justice Black put it in an unpublished memorandum, "the very existence of Government negatives [sic] any claim that citizens have a general, unconditional, unequivocal 'right to privacy' or 'to be let alone.' If every person carries with him an unconditional right to privacy..., law violators would be completely immune..." (Schwartz 1985, 276).

Second, the Court's incremental application of privacy to areas as varied as contraception, freedom from unwanted publicity, possession of pornography, abortion rights, and search and seizure problems, produced diverse understandings of privacy, a process aided by the changing membership of the Court over the years. Although the Court may create a synoptic principle of law in a single case, the nature of the judicial process requires the Court to develop such a principle on a case-by-case or incremental basis. There is much evidence that the Court is not equipped for the task of synoptically mapping the domain of any right (Snortland and Stanga 1973, 1016-31; Shapiro 1965, 155-57).

To put the distinction between the synoptic announcement and the incremental development of privacy in different terms, consider Ronald Dworkin's distinction between abstract rights and concrete rights. "Abstract rights, like the right to speak on political matters, take no account of competing rights; concrete rights, on the other hand, reflect the impact of such competition" (Dworkin 1975, 1075). Thus people may base litigation on an abstract privacy right, but the Court must determine whether there is a concrete right of privacy. In turn, by recognizing concrete rights to privacy in different situations, the Court has the opportunity to give substance and meaning to the broader abstract right of privacy.

Finally, the way the Court "found" privacy in the Constitution undercut the interpretative legitimacy of the formulation, and this combined with the intense controversy over abortion to subject the general 
right to privacy to continual attack and, perhaps, eventual evaporation. Privacy is not explicitly defined in the Constitution but is the creation of the Court applying a broad structural analysis. As such, this general right to privacy is attacked by those who see the Constitution as a discrete enumeration of specific rights rather than as a seamless document encompassing a far-reaching privacy right. Justice Black, for example, argued that "[o]ne of the most effective ways of diluting or expanding a constitutionally guaranteed right is to substitute for the crucial word or words...another word or words..." (Griswold 1965, 509). Because Griswold created the right to privacy "out of whole constitutional cloth" (O'Brien 1990, 37), the legitimacy of privacy was suspect from the beginning. Lacking a precise mooring in the Constitution and facing countervailing claims, the Court's synoptic language in Griswold did not chart a clear course for privacy law. As a result, privacy has drifted through constitutional law for twenty-five years, collecting cases as a ship collects barnacles.

In understanding the current state of privacy law it is helpful to remember Holmes's dictum that "The life of the law has not been logic: it has been experience" (Holmes 1881, 1). Thus this paper explains how the privacy right was created by Justices Brennan and Douglas, and then follows its incremental path through several areas of constitutional law. Privacy cases are analyzed under three broad categories: privacy as the right of selective disclosure, privacy as protection against government searches and seizures, and privacy as the right to make certain intimate personal and family decisions without government interference. The paper ends with speculation on the future of privacy law.

\section{The Creation of the Constitutional Right to Privacy}

American privacy law commonly is dated to the 1890 publication of "The Right to Privacy" by Samuel D. Warren and Louis D. Brandeis in the Harvard Law Review (Note 1981, 1892-1910). While never explicitly defining or describing privacy, Warren and Brandeis argued that newspaper disclosures of nondefamatory but offensive gossip required the fashioning of common law and equity remedies that went beyond the law of libel and slander (Warren 1890, 195). Under this new privacy law, traditional defenses under libel law such as truth or absence of malice would not be allowed, plaintiffs could be awarded damages for mental suffering alone, and injunctions could be issued. After Brandeis' appointment to the Court, he broadened his view of the right to privacy to include protection 
against government. His ringing dissent in the 1928 government wiretap case of Olmstead $v$. United States declared that the Framers had "conferred, as against the government, the right to be let alone--the most comprehensive of rights and the right most valued by civilized men. To protect that right, every unjustifiable intrusion by the Government upon the privacy of the individual, whatever the means employed, must be deemed a violation of the Fourth Amendment..." (Olmstead 1928, 478). However, it was not until the 1965 Griswold case that the Court declared a constitutional right of privacy.

Griswold involved an 1879 Connecticut "little Comstock act" promoted by Phineas T. Barnum, the great circus figure (Hall 1989, 161), which provided that "Any person who uses any drug, medicinal articles or instruments for the purpose of preventing conception shall be fined not less than fifty dollars or imprisoned not less than sixty days nor more than one year or be both fined and imprisoned" $(1965,480)$. The law had been challenged in Tileston v. Ullman (1943), by a physician on behalf of his patients, but the Court had refused to rule on the law because the doctor lacked standing. Then, in Poe v. Ullman (1961), the Court again avoided the issue by denying a request for a declaratory judgment against the law sought by a married couple and their physician because the case was not ripe for adjudication given the fact that only one attempt to enforce the law had been made in eighty-two years.

Justices Douglas and Harlan dissented in Poe, citing the right of privacy as a reason to overturn the law. Douglas stated that the "liberty" protected by the Fourteenth Amendment includes the right of privacy, and went on to broaden the source of privacy by stating that "This notion of privacy is not drawn from the blue. It emanates from the totality of the constitutional scheme under which we live" (1961, 520). Justice Harlan wanted to overturn the statute because privacy of the home is a "fundamental aspect" of liberty and the state statute failed to withstand the "strict scrutiny" which must be given to a law adversely impacting a fundamental right $(1961,548)$. Strict scrutiny may be contrasted with the relaxed review of the traditional rational-basis test, which upholds laws with a rational but not necessarily compelling or striking justification. As it has evolved, strict scrutiny means that when the state infringes upon a "fundamental interest" (due process) or when a governmental classification is based on an inherently "suspect" category such as race (equal protection), the Court will abandon the usual presumption of constitutionality and subject the law to active review. Under strict scrutiny, the Court throws the burden onto the government to prove that a challenged statute promotes a 
"compelling governmental interest" which should take precedence over the fundamental right and that there is a close connection between the statute and that compelling interest. If the statute passes this test, the Court usually ascertains whether the law could achieve the same purpose with a lesser impact on the exercise of constitutional rights, invalidating the statute if less intrusive means are available. ${ }^{1}$

Harlan's privacy dissent also anticipated future sexual privacy cases by recognizing that "privacy most manifestly is not an absolute. Thus, I would not suggest that adultery, homosexuality, fornication and incest are immune from criminal enquiry, however privately practiced...." These were "sexual intimacies which the State forbids altogether, but the intimacy of husband and wife is necessarily an essential and accepted feature of the institution of marriage, an institution which the State...always...has fostered and protected" (Poe 1961, 552, 553).

In Griswold, Justice Douglas' majority opinion used the right to privacy in the marital relationship to overturn the Connecticut birth control law (Schwartz 1985, 227). Griswold and Buxton had given advice to married couples on preventing conception and prescribed contraceptive devices, and were convicted as accessories under a statute which stated that "[a]ny person who assists, abets, counsels, causes, hires, or commands another to commit any offence may be prosecuted and punished as if he were the principal offender" (Griswold 1965, 480).

The conference voted seven to two in favor of striking down the law, but the majority could not state a clear theory on which to base the decision. The Chief Justice assigned the opinion to Douglas who, in conference, had suggested striking down the law because it violated the defendant's right of association under the First Amendment (Schwartz 1985, 229). Douglas did not use the word privacy until his last sentence, and he declined the invitation from oral argument to use substantive due process (President Roosevelt, after all, had put Douglas on the Court to repudiate Lochnerism). The weakness of this First Amendment position was captured by Black's note during conference: "Right of association is for me right of assembly \& rt [sic] of husband \& wife to assemble in bed is [a] new right of assembly to me" (Schwartz 1985, 237).

After reading the draft opinion, Justice Brennan wrote to Douglas that the Court's real interest was in protecting "the privacy of married couples quite apart from any interest in [First Amendment] advocacy," and that the concern for "the sanctity of the home and the right of the individual to be alone" found in the Fourth, Fifth, and Third Amendments taken together should be used to create a right to privacy "in much the 
same way as the right of association has been created out of the First" (O'Brien 1986, 256). In response, Douglas circulated another draft basing the decision on the right to privacy.

In the final opinion, Douglas retained some of his First Amendment language by reviewing previous Court decisions which applied rights not specifically guaranteed by the Constitution (e.g., the right to send one's child to a private school, the freedom to associate and have privacy in one's associations, etc.), and reasoned from these cases that the "First Amendment has a penumbra where privacy is protected from governmental intrusion." Douglas then enlarged on this conclusion by stating that the guarantees of the First, Third, Fourth, Fifth, and Ninth Amendments and previous Court cases "have penumbras, formed by emanations from those guarantees that help give them life and substance. Various guarantees create zones of privacy" (Griswold 1965, 484).

Justice Goldberg, joined by Brennan and Chief Justice Warren, concurred, stressing the importance of the Ninth Amendment in supporting the right to privacy in the marital relation. The right to privacy predated the Constitution, Goldberg maintained, and the Framers intended that all such ancient liberties should enjoy constitutional protection. The two remaining justices of the majority, Harlan and White, separately reasoned that the state lacked rational reasons to curb the liberty interest of married couples in receiving birth control information or materials and thus was in violation of the due process clause of the Fourteenth Amendment.

Justice Black vigorously dissented, stating that "I like my privacy as well as the next one, but I am nevertheless compelled to admit that government has a right to invade it unless prohibited by some specific constitutional provision" (Griswold 1965, 510). Black found nothing in the language or history of the Constitution to support such a privacy right. Justice Stewart found the Connecticut law "uncommonly silly" and "unenforceable, except in the oblique context of the present case." However, Stewart was unable to find that it violated the Constitution and concluded that the Ninth Amendment is much like the Tenth in that it merely states "a truism that all is retained which has not been surrendered" and thus is without practical force (Griswold 1965, 527, 529).

Although the privacy language of Griswold was synoptic, the facts of the case were limited to contraception by married couples. Later the Court clearly indicated that sexual privacy extended beyond the marital relationship. For example, in Eisenstadt v. Baird (1972), the Court struck down a Massachusetts law that prohibited unmarried persons from obtaining and using contraceptives. ${ }^{2}$ 
One modern definition of privacy divides it into autonomy, the right to determine whether to perform an act or undergo an experience, and selective disclosure, or the right to determine when, how, and to what extent information about oneself is communicated to others (Beardsley 1971, 56, 70). As Warren and Brandeis had wamed in 1890, newspapers were a danger to the right of selective disclosure held by ordinary citizens. One year after Griswold, a major case involving the clash of privacy with the First Amendment rights of the mass media came to the Court. Eventually decided in 1967, Time, Inc. v. Hill very nearly had the Court ruling in favor of privacy and against the press.

The case involved an article in Life magazine about a Broadway play, The Desperate Hours. The play depicted a family being held hostage in their home by escaped convicts (Schwartz 1985, 242). The Life article incorrectly stated that the play portrayed the experiences of the Hill family, and included a photograph of the house in which they had been held hostage. In fact, the play differed considerably from the actual incident, family members had refused press offers to tell their story for profit, and they had moved from the house in an attempt to put the ordeal behind them. Hill sued the publisher of Life under a 1903 New York privacy statute that allowed recovery of damages for the use "of the name or likeness of any living person without that person's consent for advertising purposes, or for the purposes of trade." The state court awarded Hill $\$ 30,000$, and the Supreme Court narrowly agreed to hear the publisher's appeal (Schwartz 1985, 240).

After a six to three vote to affirm the New York judgment, Chief Justice Warren assigned the opinion to Justice Fortas. In his draft opinion, Fortas characterized the story as "a fictionalized version of the Hill incident, deliberately distorted beyond semblance of reality by its explicit, insistent and knowingly false identification with the play" (Schwartz 1985, 261). It was "exploitation, undertaken to titillate and excite, for commercial purposes. It was not a retelling of a newsworthy incident or of an event related to a public figure" (Schwartz 1985, 264). Fortas combined a theme of "invective" against Life with a "panegyric of privacy--as broad a statement of that right as any ever made by a member of the highest court" (Schwartz 1985, 243).

Justice White's dissenting draft cautioned that the state court had indicated that the privacy statute could be applied even to true news accounts if they were commercially exploited, creating enough doubt to 
have the case held over to the next term for reargument. The day before the case was reargued, Justice Black circulated a memorandum stating that the Court's decision was not consistent with the Framer's intent "to guarantee the press a favored spot in our free society" and that he was "unable to recall any prior case...that offers a greater threat to freedom of speech and press than this one does..." (Schwartz, 1985, 278). He sharply attacked Harlan's balancing of First Amendment concerns against Court-created privacy rights, stating that it "plainly encourages and actually invites judges to choose for themselves between conflicting values, even where, as in the First Amendment, the Founders made a choice of values, one of which is a free press" (Schwartz 1985, 285). Furthermore, the Court has, "by legal legerdemain," debased "the First Amendment's promise of unequivocal press freedom" and therefore the Court is... [working under the] new slogan that 'We must always remember that it is a Constitution we are rewriting to fit the times"' (Schwartz 1985, 274-275).

Table 1. Privacy as Selective Disclosure

Cox Broadcasting v. Cohn (1975)

Invalidated a civil damage award under a Georgia privacy statute that prohibited the publication of the names of rape victims, primarily because the name had been obtained from public records.

Florida Star v. B.J.F. (1989)

Overtumed a Florida law prohibiting the mass media from printing or broadcasting the name of a sexual offense victim because the newspaper lawfully obtained the woman's name when the police mistakenly released it.

Hustler Magazine v. Falwell (1988)

The "actual malice" standard must be followed in judging an outrageous advertising parody that was intended to inflict emotional damage.

Paul v. Davis (1976)

Police distribution of a flyer containing the names and mug shots of "active shoplifters" did not violate a privacy right because this case did not involve "marriage, procreation, contraception, family relationships, and child rearing and education," and the privacy claim did not fit under "the substantive aspects of the Fourteenth Amendment" which limit privacy to guarantees that are "fundamental" or "implicit in the concept of ordered liberty."

Smith v. Daily Mail Publishing Co. (1979)

Invalidated the indictment of two newspapers for violating a state statute forbidding newspapers to publish, without written approval of the juvenile court, the name of any youth charged as a juvenile offender because the newspapers had obtained the name from witnesses, the police, and a local prosecutor.

Whalen v. Roe (1977)

Upheld New York statutes designed to control the distribution of dangerous drugs by creating a restricted and secure data bank of drug prescriptions which included the names of patients. 
Largely because of Black's spirited defense of the First Amendment, the post-reargument conference voted seven to two for reversal, with only Fortas and Warren still voting to affirm. Justice Black, as the senior justice in the majority, assigned the case to Justice Brennan (Schwartz 1985, 301). Brennan's opinion stated that the First and Fourteenth Amendments prohibit the imposition of liability upon a publication for a "newsworthy" invasion of privacy unless the "actual malice" required in libel suits by New York Times v. Sullivan (1964) is shown. That is, the plaintiff must show "knowing or reckless falsity in the publication" (Time, Inc. v. Hill 1967, 397).

Following Time v. Hill, the Court remained reasonably consistent in ruling against privacy claims when faced with state laws protecting individual privacy against invasion by the news media. As Justice Stewart explained in a concurrence, " [w] hatever the ratio decidendi of Griswold, it does not recognize a general interest in freedom from disclosure of private information" (Whalen v. Roe 1977, 608). Table 1 lists cases in which privacy laws or claims were not upheld against contrary claims, especially the rights of the mass media under the First Amendment.

\section{Privacy as Protection from Government Searches and Seizures}

Beginning with Justice Harlan's concurring opinion in Katz v. United States (1967), the Court applied a privacy test to Fourth Amendment cases. However, Harlan did not define privacy except in the reflexive sense of being that which is violated by an unreasonable search and seizure. There are two parts to Harlan's "reasonable expectation of privacy" test: "first, that a person have exhibited an actual (subjective) expectation of privacy and, second, that the expectation be one that society is prepared to recognize as 'reasonable"' (Katz 1967, 361). Thus formulated, privacy in search and seizure cases is not a fundamental right which must be protected by strict scrutiny of governmental actions; rather, it is a guideline or balancing test to be used in applying the Fourth Amendment to modern conditions and in evaluating exceptions to an otherwise exacting interpretation of the Fourth Amendment.

Even before the application of Harlan's privacy test, Fourth Amendment law was highly complex and inconsistent. While this is not the place to review the voluminous body of Fourth Amendment cases which involve privacy, it is safe to generalize that the application of the second part of the "reasonable expectation of privacy" test has not significantly expanded the protection of the Fourth Amendment. ${ }^{3}$ 
Perhaps the clearest example of the limited protection of the expectation of privacy standard was seen in California v. Greenwood (1988), where the Court held that placing one's garbage bags on the curb to be collected ends any reasonable expectation of privacy. Lacking enough evidence of illegal drug activity to obtain a search warrant, the police had on two occasions arranged with the trash collector to pick up opaque plastic garbage bags placed on the curb outside Greenwood's house, and each time used the evidence found in the trash to obtain a search warrant. The Court reasoned that while Greenwood may have had a subjective expectation that his garbage was private, this was not reasonable given the fact that the trash was voluntarily left for collection in a container and place where almost anyone could have access to it. In this respect, Greenwood resembles Olmstead more than Katz. In Olmstead, the Court stated that "The reasonable view is that one who installs in his house a telephone instrument with connecting wires intends to project his voice to those quite outside, and that the wires beyond his house and messages while passing over them are not within the protection of the 4th Amendment" $(1928,466)$.

In the area of the Fourth Amendment, the Court has not provided a "bright line" privacy standard by which to judge government actions. The Court adapted the Fourth Amendment to modern technology and recognized the American desire for privacy in $\mathrm{Katz}$, but failed to move beyond a general balancing test. However, in order to adapt the literal words of the Fourth Amendment to the realities of modern life, a test or concept that reflects the fundamental values or meaning of the Amendment must be used (Murphy 1986, 299-300). Thus Justice Harlan's “reasonable expectation of privacy" test both captures that fundamental meaning and provides a standard by which one may judge government actions.

\section{Privacy as Protection from Government Interference in Intimate Personal and Family Decisions}

In Stanley v. Georgia (1969), the Court used the First Amendment to create a new personal privacy right to possess obscene material in the home; however, in subsequent cases the Court refused to extend this right to protect the viewing of obscene movies outside the home, homosexual relations within the home, and the private possession of child pornography. In Stanley, Justice Marshall, writing for the Court, held that the Constitution forbids government from making private possession of obscene matter a crime, stating that "Whatever may be the justifications for 
other statutes regulating obscenity, we do not think they reach into the privacy of one's own home. If the First Amendment means anything, it means that a State has no business telling a man sitting alone in his own house what books he may read or what films he may watch" $(1969,565)$.

In Paris Adult Theatre $I v$. Slaton, the Court refused to extend Stanley to a movie theater which showed obscene films to consenting adults, stating that Stanley "was hardly more than a reaffirmation that 'a man's home is his castle," and that the "idea of a 'privacy' right and a place of public accommodation are, in this context, mutually exclusive" $(1973,49,66,67)$. In addition, the Court refused an invitation to merge Fourth Amendment privacy law with First Amendment privacy law by applying the "reasonable expectation of privacy" test of Katz to the adult theater.

By a five to four vote, the Court also refused to extend the homecentered privacy view of Stanley in Bowers v. Hardwick (1986), which involved a claim of protection for acts of homosexual sodomy committed in the home. Justice Powell initially favored overturning the Georgia statute, but apparently changed his mind because, for him, Justice Blackmun's proposed opinion was too "sweeping in its language and use of precedents," swinging the Court the other direction (O'Brien 1990, 257). Blackmun, for example, relied on Powell's opinion in Moore v. City of East Cleveland (1977). In Moore, Powell used privacy in the home to strike down a zoning law which limited rental housing to "single families" and thus excluded a grandmother and grandson from living together. Justice Powell "never dreamed that [this case] would be a basis for limiting the state's power to regulate sodomy" (O'Brien 1990, 257).

Justice White, writing for the Court in Bowers, echoed Harlan's Poe dissent and reasoned that "otherwise illegal conduct is not always immunized whenever it occurs in the home" and stated that the Court was "unwilling to start down" a new road by allowing voluntary homosexual acts to be protected in the home while "leaving exposed to prosecution adultery, incest and other sexual crimes even though they are committed in the home." White found two sources for fundamental rights which are not expressly granted in the Constitution: first, those "implicit in the concept of ordered liberty," and, second, those "deeply rooted in the nation's history and tradition." However, "neither of these formulations would extend a fundamental right to homosexuals to engage in acts of consensual sodomy" given the long history of laws against sodomy. Finding no fundamental right to engage in homosexual conduct, the Court upheld the law because it withstood rational scrutiny. That is, even if the law was 
based solely on the view that homosexual sodomy is immoral, "if all laws representing essentially moral choices are to be invalidated under the Due Process Clause, the court will be very busy indeed" $(1986,191,192,196)$.

The limited nature of Stanley was confirmed in Osborne v. Ohio (1990), where the Court found that the private possession of child pornography could be subject to criminal prosecution. The Court distinguished Osborne from Stanley because the Georgia law was designed to prevent the minds of viewers from being poisoned by obscenity while the Ohio statute had the purpose of protecting the victims of child pornography by destroying the market for such materials, a purpose the Court had upheld in New York v. Ferber (1982). Thus the First Amendment may bar states from attempting to control a person's private thoughts, but it does not bar a state from attempting to decrease the sexual exploitation of children by penalizing those who possess and view child pornography.

Privacy most inflamed the nation and the courts when, in Roe $v$. Wade (1973), it was held to protect a woman's right to obtain an abortion (O’Brien 1986, 35-37; Schwartz 1985, 238-39; Johnson 1984, 4-14). In Roe, Justice Blackmun, writing for the majority, stated that the "right of privacy,...founded in the Fourteenth Amendment's concept of personal liberty and restrictions upon state action,...is broad enough to encompass a woman's decision whether or not to terminate her pregnancy," and the choice should be left to the woman and her physician $(1973,153)$.

Roe applied strict scrutiny to abortion laws. Because a woman's right to privacy was fundamental, Texas had to demonstrate a compelling state interest in protecting the life of the fetus or the health of the mother to prohibit or regulate abortion. The Court rejected Texas' contention that this compelling interest starts at the moment of conception, finding that one becomes a "person" under the Constitution "postnatally." In place of conception, the Court recognized the state's interest in protecting the life of the fetus as compelling when the fetus becomes "viable" or capable of "meaningful life outside the mother's womb," thus mixing the constitutional issue with the factual issue of the current state of medical technology. The Court defined viability in terms of the beginning of the third trimester of pregnancy, when the state was free to protect the life of the unborn by prohibiting abortion except where necessary to preserve the life or health of the mother. The Court recognized a limited state interest in protecting the health of the mother by regulating the abortion procedure during the second trimester, but gave the pregnant woman and her attending physician the exclusive right to make the abortion decision during the first trimester because maternal mortality in abortion during the first 
trimester may be less than maternal mortality in normal childbirth.

Justice Rehnquist, in dissent, accused the majority of "judicial legislation" for the trimester formula and attacked the majority's action in transplanting the compelling governmental interest test (strict scrutiny) from the equal protection realm to the due process area. Justice White also dissented, finding "nothing in the language or history of the Constitution to support the Court's judgment" (1973, 221; also see Epstein 1976, 159186).

In Roe the Court could have struck down the Texas statute on grounds of vagueness (Schwartz 1988, 83, 117-118), as Blackmun intended in his initial draft, although this would have been an unsuitable basis for striking the Georgia statute in the companion case of Doe $v$. Bolton (1973). Or it could have stopped short of the strict scrutiny required for a fundamental right, and used rational-basis scrutiny in order to overturn the law because it violated a "liberty interest" protected by the Fourteenth Amendment's due process clause. Instead, the Court extended the privacy right first established in Griswold, leaving the Court open to considerable criticism on constitutional grounds (Schwartz 1988, 87-88, 93-102). As with Griswold, many who favored the results criticized the Court for resting its decision on a constitutional right to privacy; however, unlike Griswold, even the results of Roe proved to be highly controversial (O'Brien 1986, 36).

After Roe, the Court was faced with several cases involving the issue of providing public funds for abortion. Here the Court faced the question of whether the right to abortion, like so many other rights, merely provided the "negative liberty of non-interference," or did it also include the "positive liberty of self-realization" (Berlin 1970, lvii), thus empowering poor women in their choices. In a 1977 decision decided on statutory rather than constitutional grounds, the Court upheld Pennsylvania's denial of medical assistance for non-therapeutic abortions in Beal v. Doe. On the same day, the Court, in Maher v. Doe (1977), allowed prohibitions on using government funds to pay the expenses of abortion, opining that the state's decision to fund childbirth but not abortion, while making childbirth more attractive than abortion, did not unduly restrict access to abortions. In Harris v. McRae (1980), the Court upheld congressional actions which prohibited the use of federal Medicaid funds for even medically necessary abortions, reasoning that the Fourteenth Amendment "does not confer an entitlement to such funds as may be necessary to realize all the advantages" of the liberty protected by the due process clause $(1980,297,318)$. Thus the government may not place undue 
obstacles in the path of a woman's decision to have an abortion, but it does not have an obligation to remove obstacles that it did not create, including poverty. Privacy was negative liberty, merely obligating government not to interfere unduly with a woman's abortion choice.

Support for Roe began to wear away on the Court. First, Burger, who had been part of the seven-to-two majority in Roe, decided that "we should reexamine Roe" in Thornburgh v. American College of Obstetricians (1986). Then Rehnquist replaced Burger as Chief Justice in 1986, and the vacant seat was taken by Antonin Scalia. Anthony Kennedy replaced Powell in 1988, setting the stage for a major overhaul of Roe.

In Webster v. Reproductive Health Services (1989), a Missouri abortion case was decided without application of the right to privacy, a fact which Blackmun complained about in his dissent. In answering Blackmun, Chief Justice Rehnquist, writing for the Court, stated that abortion should be considered a "liberty interest" and not a "fundamental right" or "a limited fundamental constitutional right." The significance of this is that Court has never used "liberty interest" to describe a fundamental right deserving of the highest degree of constitutional protection.

In Webster, a bitterly divided Court furnished five opinions with no single opinion capturing a majority. Only Justices Kennedy and White joined Chief Justice Rehnquist's opinion in upholding Missouri's regulations and thus narrowing Roe, while O'Connor and Scalia concurred in separate opinions, respectively. Blackmun, Brennan, Marshall and Stevens wanted to leave Roe untouched while Rehnquist, Scalia, White and Kennedy wanted to overturn Roe. O'Connor avoided both camps but cast the deciding vote by refusing to reconsider Roe but agreeing to uphold the abortion restrictions because they did not unduly burden a woman's abortion decision and thus did not conflict with Roe.

In a much less noticed 1989 privacy case, Justice Scalia provided further groundwork for replacing strict scrutiny with the rational-basis test, and (though joined only by the Chief Justice) laid the basis for using a narrow reading of historical traditions to determine whether one has a liberty interest under the Fourteenth Amendment. Michael H. and Victoria D. v. Gerald D. (1989) involved the attempt of a probable biological father, Michael H., to establish paternity and visitation rights with Victoria D., a child born to a married couple, Carole and Gerald D. Under California law, a child born to a married woman living with her husband is presumed to be a child of the marriage, a presumption which may be challenged only by the husband or wife under limited circumstances. Michael $\mathrm{H}$. argued that this law violated his due process right to establish 
his paternity and that the state's interest in protecting the marital union was insufficient to deny his parental relationship. The Court rejected this claim, finding that he had no constitutionally protected "liberty interest" in a parental relationship with Victoria, and that the state's interest in holding the husband responsible for the child and protecting the integrity and privacy of the family unit had a rational basis.

Justice O'Connor, joined by Justice Kennedy, concurred in the judgment but registered her disagreement with Scalia's sketch in footnote 6 "of a mode of historical analysis to be used when identifying liberty interests...that may be somewhat inconsistent with our past decisions in this area," specifically with Griswold and Eisenstadt (Michael H. 1989, 111). In footnote 6 , Scalia rejected Brennan's contention that "parenthood is an interest that historically has received our attention and protection" by stating that historical analysis should focus on "the most specific level at which a relevant tradition protecting, or denying protection to, the asserted right can be identified." Thus the rights of adulterous natural fathers traditionally have not been protected, and it is inappropriate to enlarge this historical category to include "parenthood." Scalia argued that while a broad reading of history leaves "judges free to decide as they think best..., a rule of law that binds neither by text nor by any particular, identifiable tradition, is no rule of law at all" $(1989,109)$.

Justice Brennan, joined by Marshall and Blackmun, focused on rejecting Scalia's historical analysis because it "portends a significant and unfortunate departure from our prior cases and from sound constitutional decision making...." Brennan found " $[\mathrm{t}]$ he plurality's reworking of our interpretive approach....all the more troubling because.... $\mathrm{t}$ ] his is not a case in which we face a 'new' kind of interest, one that requires us to consider for the first time whether the Constitution protects it" $(1989,115,118)$.

Up until 1990, the "right to die" for irreversibly vegetative patients who have no consciousness and who are kept alive on life-support systems was assumed to be included under the federal constitutional right to privacy as well as state constitutional privacy and the common law (Nankivell 1990, 67). In Re Quinlan (355 A.2d 647 [N.J. 1976]), decided by the New Jersey Supreme Court in 1976, is the leading decision in this area. However, Webster and Michael $H$. led to a major "right to die" case being decided on the basis of a Fourteenth Amendment "liberty interest." Even Brennan, the intellectual founder of the constitutional right to privacy, avoided privacy language in his dissent, leaving only Stevens to apply the privacy precedents in his dissent.

In Cruzan v. Director, Missouri Department of Health (1990), the 
Court in a five-to-four vote affirmed that a competent person has a liberty interest to refuse medical treatment when this interest is not outweighed by a relevant state interest. However, the Fourteenth Amendment does not require a state to accept the "substituted judgment" of close relatives of an incompetent person unless there is substantial proof that the views of these surrogates reflect the views of the patient. (The trial judge had accepted the parents' decision to remove a surgically implanted feeding tube because it was in the best interests of Nancy Cruzan and because of testimony that Nancy Cruzan indicated that she would not wish to continue her life unless she could live in a halfway normal manner. However, the Missouri Supreme Court applied a heightened evidentiary standard of "clear and convincing proof" to testimony on Nancy Cruzan's wishes and held that these statements were not reliable to determine her intent.) Thus the state's "unqualified" interest in preserving life as expressed in its Living Will Statute was sufficient to prevent the parents of Nancy Cruzan from ending her life even though she had spent over seven years lying in a persistent vegetative state.

Brennan, joined by Marshall and Blackmun, reasoned that the right to be free of unwanted medical attention is a fundamental right protected by strict scrutiny. He stated that the testimony of close friends and family members often is the best evidence of what the patient's choice would be, rejecting as excessive the "clear and convincing proof" standard accepted by the majority. Brennan found no compelling state interest in keeping Nancy Cruzan alive, and concluded that "Nancy Cruzan is entitled to choose to die with dignity" $(1980,257)$. However, Brennan, the founder of privacy law, did not use privacy language, a clear indication of Rehnquist's success in removing privacy as a major consideration in abortion and right to die cases.

In contrast to Brennan, Justice Stevens, also in dissent, cited privacy precedents to conclude that the "individual privacy of the human body is obviously fundamental to liberty" and thus Missouri had unreasonably intruded upon traditionally private matters encompassed within the liberty protected by the due process clause $(1990,282) .{ }^{4}$

\section{The Future of Privacy}

In 1965, when the Court created the right to privacy, the language if not the facts of the case suggested that privacy was a fundamental, general right that would protect individuals from government and other individuals. Faced with cases involving a variety of areas, the Court considerably 
narrowed the approach suggested by Griswold. With Hill, it became clear that privacy was a highly restricted interest when it came in conflict with the First Amendment. Even in cases involving state action, Griswold created no general right to selective disclosure or freedom from unwanted publicity. In $\mathrm{Katz}$, the Court applied a balancing test to Fourth Amendment cases but did not significantly expand or elaborate on a fundamental privacy right in search and seizure cases. To many, Stanley signalled that the Court was ready to declare that privacy protects people from government regulation of their sexual activities, at least in the privacy of their homes. Despite Stanley, the Court was unwilling in Bowers to expand privacy rights beyond contraception to include sodomy or homosexual behavior. Finally, in Osborne, the Court narrowed Stanley by excluding First Amendment privacy protection for child pornography. By applying strict scrutiny in privacy matters, the Court dramatically extended the right to privacy in Roe; however, it also shifted emphasis from the shadows and emanations of the First, Third, Fifth, and Ninth Amendments as sources of privacy, relying more on the Fourteenth Amendment, and substituting the word "privacy" for the word "liberty" in the due process clause. This substitution of terms, the application of strict scrutiny, and the controversial nature of abortion, led to charges that the Court was acting as a "superlegislature." Thus Roe planted the interpretative and political seeds of its undoing, allowing Rehnquist and his new allies on the Court to return privacy to a liberty interest protected only by rational-basis scrutiny and, perhaps, discovered by a narrow historical analysis intolerant of new privacy claims.

The changing composition of the Court also served to erode the synoptic version of privacy. With the retirement of Justice Brennan, the true founder of the constitutional right to privacy, only Justice White, who concurred, remains from the majority which handed down Griswold. Of those on the Court when Roe was decided, only three justices remain: Rehnquist and White, both of whom dissented, and Marshall. Given the appointment of David Souter and President Bush's quest for justices who do not "legislate," it appears likely that the Court will continue the transformation of privacy from a fundamental right (Griswold) protected by strict scrutiny (Roe) into a "liberty interest" (Webster) protected by rational-basis scrutiny. In the unlikely event that Scalia and Rehnquist have their way, these privacy-rights-turned-liberty-interests will be given a narrow historical interpretation, providing little room for innovation. Most probably, the privacy interests protected by the Constitution will be recognized in cases decided under the First, Fourth, Fifth, and Fourteenth 
Amendments, perhaps without explicit privacy language, and the Court will avoid the Ninth Amendment and the sweeping privacy language of Griswold and Roe.

\section{NOTES}

${ }^{1}$ Strict scrutiny is similar to the "substantive due process" analysis of Lochner v. New York (1905), in which the Court refused to accept a public health justification for a law setting the maximum work hours of bakers. The Court abandoned substantive due process in West Coast Hotel v. Parrish (1937), but revived it for equal protection and First Amendment cases during the Warren Court (1953-69). The Warren Court frequently cited Justice Stone's footnote 4 in United States v. Carolene Products Co. (1938, 144), which suggested that the Court should give "more exacting judicial scrutiny" to statutes restricting the political process or aimed at discrete and insular religious, national, or racial minorities. Stone wanted to "leave economic policy making to democratically elected officials while still not placing other civil liberties...completely in the hands of representatives of the majority" (Murphy 1986, 483).

${ }^{2}$ New York state prohibitions on advertising contraceptives and selling nonprescription contraceptives to minors were struck down in Carey v. Population Services (1977). Finally the Court struck down a federal law which prohibited the mailing of unsolicited advertisements for contraceptives in Bolger v. Young's Drug Products Corporation (1983).

${ }^{3}$ The government completely or largely prevailed in California v. Ciraolo (1986), Florida v. Riley (1989), National Treasury Employees Union v. Von Raab (1989), New Jersey v. T.L.O. (1985), Oliver v. United States, (1984), Skinner v. Railway Labor Executives' Association (1989), United States v. Dunn (1987), United States v. Montoya de Hernandez (1985), and Washington v. Chrisman (1982).

${ }^{4}$ Eventually, after hearing new evidence and using the "clear and convincing proof" standard, a Missouri judge allowed Nancy Cruzan's feeding tube to be removed and she died in 1990.

\section{REFERENCES}

Abraham, Henry J. 1987. The Judiciary: The Supreme Court in the Governmental Process. Boston: Allyn and Bacon.

Beal v. Doe. 1977. 432 U.S. 438.

Beardsley, Elizabeth L. 1971. "Privacy: Autonomy and Selective Disclosure." In J. Roland Pennock and John W. Chapman, eds. Privacy. New York: Atherton Press.

Berlin, Isaiah. 1970. Four Essays on Liberty. New York: Oxford. Bolger v. Young's Drug Products Corp. 1983. 463 U.S. 60.

Bowers v. Hardwick. 1986. 478 U.S. 186.

California v. Greenwood. 1988. 108 S.Ct. 1625.

California v. Cirado. 1986. 476 U.S. 207.

Carey v. Population Services. 1977. 431 U.S. 678. 
Cooley, Thomas M. 1888. A Treatise on the Law of Torts. Chicago: Callaghan. Cox Broadcasting v. Cohn. 1975. 429 U.S. 469.

Cruzan v. Director, Missouri Dept. of Health. 1990. 111 L. Ed. 2 d 222.

Curry, James A., Richard B. Riley, and Richard M. Battistoni. 1989. Constitutional Government: The American Experience. St. Paul: West.

Doe v. Bolton. 1973. 410 Ct. 69.

Domino, John C. 1990. "Judicial Innovation and the Right to Privacy: An Application of A Diffusion of Innovation Model." Paper presented at the annual meeting of the Southwest Political Science Association.

Dworkin, Ronald. 1975. "Hard Cases." Harvard Law Review 88: 1057-109.

Eisenstadt v. Baird. 1972. 405 U.S. 438.

Epstein, Richard A. 1976. "Substantive Due Process by any Other Name: The Abortion Cases." Supreme Court Review 159-185.

Fisher, Louis. 1990. American Constitutional Law. New York: McGraw-Hill.

Florida v. Riley. 1989.109 Ct. 69.

Florida Star v. B.J.F. 1989. 109 S.Ct. 2603.

Gavison, Ruth. 1980. "Privacy and the Limits of the Law." Yale Law Journal 89: 42163.

Griswold v. Connecticut. 1965. 381 U.S. 479.

Hall, Kermit L. 1989. The Magic Mirror: Law in American History. New York: Oxford. Harris v. McRae. 1980. 448 U.S. 297.

Hustler Magazine v. Falwell. 1988. 108 S.Ct. 876.

In Re Quinlan. 1976. 355 A. 2d 647 (N.J.).

Johnson, Charles A., and Bradley C. Canon. 1984. Judicial Policies: Implementation and Impact. Washington, D.C.: Congressional Quarterly.

Katz v. United States. 1967. 389 U.S. 347.

Lochner v. New York. 1905. 198 U.S. 45.

Maher v. Doe. 1977. 432 U.S. 45.

Michael H. and Victoria D. v. Gerald D. 1989. 105 L. Ed. 2 d 91.

Moore v. City of East Cleveland. 1977. 431 U.S. 494.

Mill, John Stuart. 1951. On Liberty. In John Stuart Mill, Utilitarianism, Liberty, and Representative Government. New York: E. P. Dutton.

Murphy, Walter F., James E. Fleming, and William F. Harris, II. 1986. American

Constitutional Interpretation. Mineola, New York: The Foundation Press.

National Treasury Employees' Union v. Von Raab. 1989. 109 S.Ct. 1384.

New Jersey v. T.L.O. 1985. 469 U.S. 325.

New York v. Ferber. 1982. 458 U.S. 747.

New York v. Sullivan. 1964. 376 U.S. 254.

Nankivell, Ross. 1990. "This Far and No Further: Is There a Constitutional Right to Die?" ABA Journal. April 76: 66-69.

Note. 1973. "Privacy and the First Amendment." Yale Law Journal 82: 1462-81.

Note. 1981. "The Right to Privacy in Nineteenth Century America." Harvard Law Review 94: 1892-1910.

O'Brien, David M. 1990. Storm Center: The Supreme Court in American Politics. New York: W. W. Norton.

Oliver v. United States. 1984. 466 U.S. 170.

Olmstead v. United States. 1928. 277 U.S. 438. 
Osborne v. Ohio. 1990. 109 L. Ed. 2 d 98.

Paris Adult Theatre I v. Slaton. 1973. 413 U.S. 49.

Paulv. Davis. 1976. 424 U.S. 693.

Poe v. Ullman. 1961. 367 U.S. 497.

Skinner v. Railway Labor Executives' Association. 1989. 109 S.Ct. 1402.

Smith v. Daily Mail Publishing Co. 443 U.S. 97.

Stanley v. Georgia. 1969. 394 U.S. 557.

Schwartz, Bernard. 1985. The Unpublished Opinions of the Warren Court. New York: Oxford.

Schwartz, Bernard. 1988. The Unpublished Opinions of the Burger Court. New York: Oxford.

Shapiro, Martin. 1965. "Stability and Change in Judicial Decision-Making: Incrementalism or Stare Decisis." Law in Transition Quarterly 2: 134-157.

Snortland, Neil E. and John E. Stanga. 1973. "Neutral Principles and Decision-Making Theory: An Alternative to Incrementalism." The George Washington Law Review 41: 1006-1032.

Thornburgh v. American College of Obstetricians. 1986. 476 U.S. 747.

Tileston v. Ullman. 1943. 318 U.S. 44.

Time, Inc. v. Hill. 1967. 385 U.S. 374.

United States v. Dunn. 1987. 480 U.S. 294.

United States v. Carolene Products Co. 1938. 304 U.S. 144.

United States v. Montoya de Hernandez. 1985. 473 U.S. 531.

Warren, Samuel D., and Louis B. Brandeis. 1890. "The Right to Privacy." Harvard

Law Review 4: 193-220.

Washington v. Chrisman. 1982. 455 U.S. 1.

Webster v. Reproductive Health Services. 1989. 109 S.Ct. 3040.

West Coast Hotel v. Parrish. 1937. 300 U.S. 379.

Whalen v. Roe. 1977. 429 U.S. 589. 38. 304 U.S. 144. 